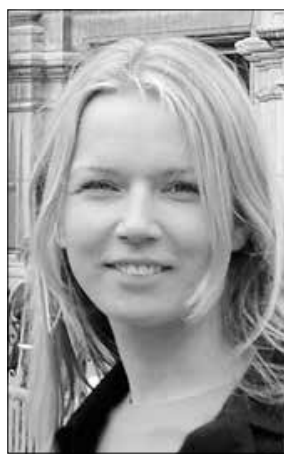

https://doi.org/10.24101/logos.2017.47

Gauta 20170419

\title{
VAIDA ASAKAVIČIŪTE்
}

Vilniaus Gedimino technikos universitetas, Lietuva

Vilnius Gediminas Technical University, Lithuania

\section{KULTÜROS KRIZĖS SAMPRATA OSVALDO SPENGLERIO FILOSOFIJOJE \\ The Concept of Cultural Crisis in Osvald Spengler's Philosophy}

\author{
SUMMARY
}

The article analizes the insights of the famous German philosopher. Osvald Spengler, on the evolution of civilization and the causes of cultural crisis. In the first part and on the basis of a disjunction between culture and civilization, the article demonstrates that in Spengler's cultural studies, the culture presents vital trends of the evoliution of a society: development, freedom of the personality, the period of a creative improvement and prosperity; civilization as the last phase of culture marks the death and stagnation time, and at the same time expresses a cultural crisis as a recession of the authentic creation, finally determinining the end of culture. The second part focuses on the relationships between cities and villages; the analysis highlights the opposition between civilization and cultural development. The study examines Spengler's position on the causes of culture crisis. It shows that in a rural environment the vital cultural spirit of individuality, intuition, naturality, freedom, tradition, values and religiosity is flourishing. City, megapolis, which is a product of civilization, conversely consolidates the urban environment. That environment determines the mass cultural spread, the devaluation of traditional values, consumerism, pragmatism, the fashion cult and the sketchy standards of beauty. Here destructively runs the cultural evolution. Cultural evolution destroys authentic creativity and cultural values.

\section{SANTRAUKA}

Straipsnyje analizuojamos garsaus vokiečių mąstytojo, gyvenimo filosofijos tradicijų tęsėjo Osvaldo Spenglerio įžvalgos apie civilizacijos raidos dėsningumus ir kultūros krizės gelmines priežastis. Pirmoje dalyje, remiantis kultūros ir civilizacijos disjunkcija, parodoma, kad Spenglerio koncepcijoje, plètojant vokiečių kultūros filosofijos tradicijas, kultūra išreiškia gyvybingas visuomenės raidos tendencijas - tobulèjimą, asmens laisvę, kūrybinio augimo ir klestẻjimo laikotarpį; civilizacija, kaip paskutinioji jos fazė, žymi mirties ir stagnacijos laiką, o kartu išreiškia kultūros krizę kaip autentiškos kūrybos nuosmukį, galiausiai nulemdama kultūros pabaigą. 
Antroje dalyje dėmesys sutelkiamas į miesto ir kaimo santykius, kurių analizè išryškina ciklinės civilizacijos ir kultūros raidos prieštaringumą. Nagrinėjamas Spenglerio požiūris i kultūros krizės priežastis ir apraiškas, parodant, jog kaimo aplinkoje klesti gyvoji kultūros dvasia, individualumas, intuicija, natūralumas, laisvè, tradicijos, vertybès, religingumas. Miestas - megapolis, kuris yra civilizacijos produktas, priešingai, ¡̨tvirtina aplinką, kuri nulemia masinės kultūros paplitimą, tradicinių vertybių nuvertinimą, vartotojiškumą, pragmatizmą, mados kultą ir paviršutiniškus grožio standartus, kurie destruktyviai veikia kultūros ir meno raidą, sunaikindami autentišką kūrybą bei kultūrines vertybes ir formas.

$\mathrm{K}$ ultūros sąvoka yra labai plati ir daugiareikšmè, todèl neturi giežtos definicijos, ji turi daugybę skirtingų semantinių prasmių ir raiškos formų. Be to, kultūra nèra stabilus, sustingęs reiškinys - ji nuolatos savo raidoje kinta, atsinaujina. Daugelis kultūros filosofu individą iškelia kaip svarbiausią kultūros kūrëją. Pagrịsdamas kultūros ir kūrybos santykị, lietuviškos kultūros filosofijos atstovas Antanas Maceina nurodo, jog "kultūrą mes suprantame kaip žmogiškąją kūrybą ir šioje kūryboje matome giliausią kultūros esmę ${ }^{\text {"1. }}$. Juozas Girnius, iškeldamas nenutraukiamas kultūros ir žmogiškojo gyvenimo sąsajas, pažymi, kad „kultūra drauge yra žmogiškosios egzistencijos būtinoji sąlyga ir jos išraiška“"2.

Šiuo metu labai išsiplètęs dabartinès kultūros studijų tyrimų laukas rodo, kad i kultūrą jau žvelgiama ne kaip i̇ išskirtiniu religijos ar meno kūriniu visuma, bet kaip i̇ visą mus supantị kasdienybès, ivvairiausiu žmogaus veiklos formu pasauli ir netgi žmogaus gyvenimo būdą. Todèl svarbu suprasti ir kritiškai įvertinti tuos radikalius pokyčius, kurie nulemia dabartinès kultūros krizę ir tradiciniu vertybiu nuosmuki, nes stiprejjanti suprekintos kultūros krizè neabejotinai paliečia visos valstybès, tautos, visuomenès ir atskiro individo egzistencija, kūryba, pasaulèžiūrą ir mąstymą. Šios problemos yra ypač aktualios ir svarbios šiandien, kuomet dabartinëje Vakaru visuomenèje globalizacijos procesai ir spartus technologiju plètojimasis vis labiau skatina kultūrinès niveliacijos tendencijas, tradicinių humanistinių vertybių nuvertèjimą, materializma, susvetimèjima, pragmatizmą, formuoja masinę, vartotojišką pseudokultūrą, bet ne skatina autentiškos kultūros išlikimą.

Todèl šiandien itin aktualu atsisukti i šias problemas gvildenusių XX a. pradžios klasikų veikalus ir naujai kritiškai pažvelgti i juos. I klasikinès humanistinès kultūros tradicijos krizę vieni pirmųjų savo dèmesi atkreipe neklasikinès ir gyvenimo filosofijos šalininkai Arthuras Schopenhaueris, Sørenas Kierkegaard'as, Friedrichas Nietzsche bei jų sekejjai Henri Bergsonas, Georgas Simmelis, José Ortega y Gassetas, kurie, kritikuodami pamatinius spekuliatyvios klasikinès kultūros filosofijos principus, iškèlè siekị atnaujinti Vakaru filosofija, mena, moralę. Kultūrinès krizès klausimus taip pat svarstė egzistencialistinès srovès atstovai, tokie kaip Antanas Maceina, Juozas Girnius, Karlas Jaspersas, Nikolajus Berdiajevas ir kt. Paminètų mąstytojų veikaluose yra savitai nušviečiamas Vakaru istorijos ir kultūros likimas. Ju filosofinèje kūryboje kultūros krizè interpretuojama įvairiai - kaip Vakaru dekadansas, nihilizmas ar vertybiu krizè, arba kaip kultūros tragizmas, masių sukilimas arba Vakaru istorijos pabaiga ir pan. 
Tad siekiant geriau perprasti dabartinèje visuomenėje išryškẻjusias kultūrinės krizès priežastis ir ateities poslinkių tendencijas, tikslinga kritiškai įvertinti mintis tų Vakarų mąstytojų, kurie dar XIX a. filosofiniuose apmąstymuose gvildeno šias problemas. Vienas ryškiausių iš jų buvo Nietzsche's gyvenimo filosofijos sekèjas Spengleris, kuris pasinèrè i civilizacijos istorijos filosofines problemas, ǐžvalgiai analizavo kultūros krizès apraiškas. Jo programinis veikalas Der Untergang des Abendlandes (Vakaru saulèlydis, 1918) tapo iššūkiu ir viena nuožmiausių Vakarų kultūros kritikų. Spenglerio istoriosofinès idejjos turèjo didelès ittakos vèlesniems kultūros ir civilizacijos tyrinejjimams. Vis dèlto daugelis dabarties kultūrologų, kultūros ir filosofijos istorijos kritikų iki šiol nesutaria ir prieštaringai vertina šio mąstytojo palikimą.
Neabejotina, kad daugeliu atžvilgių Spenglerio mintys buvo izžvalgios ir pranašiškos - jos įvardija Vakarų kultūros krizinę būklę, nurodo jos tolimesnị likimą. Paties mąstytojo žodžiais tariant, perejjimas iš kultūros į civilizaciją Vakaruose ivyko jau XIX a. Vadinasi, esame civilizacijos stadijoje, o tai reiškia, kad Vakarų kultūra išgyvena krizę ir arteja prie pabaigos. Tad šio straipsnio tikslas - išnagrinèti Spenglerio kultūros krizès samprata, atskleisti krizès priežastis ir padarinius. Remiantis kultūros ir civilizacijos disjunkcija, parodyti, jog civilizaciniai pokyčiai turi neigiamą poveiki kultūrai bei žmogaus asmenybei, jo gyvenimo aplinkai. Siekiama pagrịsti, kad kultūrinę krizę lemia civilizacijos iškilimas, kuris sukelia žmogaus asmenybès dvasinę krizę, kūrybinių jègų ir potencialo mažèjimą bei kūrybinès aplinkos pokyčius.

\section{KULTŪRA VERSUS CIVILIZACIJA}

Spenglerio kultūros filosofijoje keliamos dvi esminès sąvokos - kultūra ir civilizacija. Ši kultūros ir civilizacijos disjunkcija žymi radikaliai skirtingus kultūrų istorijos raidos etapus bei padeda giliau suvokti ir apibrèžti kultūros samprata, jos krizès priežastis ir apraiškas. Civilizacija, kuri klesti dabarties Vakarų Europoje, išreiškia kultūrinio ciklo pabaigą. Tai periodas, neturintis nieko bendra su autentiška kultūra. Spengleris skelbia kategoriškas ir paradoksalias ižvalgas. Viena vertus, šis etapas žymi aukštos modernios technikos, sistemos progresa, o kita vertus - kultūros regresą, autentiškos kūrybos stagnaciją ir kultūros formu mirtị. Anot Andrijausko, Spengleris iš Nietzsche's perèmè kritinị požiūrị i naujausias Vakarų civilizacijos tendencijas, Europos dekadanso ideją, kurią pervardijo Vakaru saulèlydžiu, ir dar daugeli kitų kultūrinių idejjų ${ }^{3}$.

Šiame skyriuje analizuojama su gyvenimo filosofijos tradicija glaudžiai susijusi kultūros ir civilizacijos takoskyra yra svarbus kultūrologijos ir kultūros filosofijos klausimas, kuris iki šiol neturi bendros nusistovejjusios pozicijos ir bendro sutarimo. L. Donskio teigimu, panašias idejjas, žyminčias, kad civilizacija yra kultūros gyvybės ciklo pabaiga, krizinè kultūros proceso fazè, destruktyvi letalinè kultūra, galima aptikti K. Leontjevo, V. Solovjovo, F. Dostojevskio kūryboje, taip pat šias nuostatas yra plètoję A. Schweitzeris, N. Berdiajevas, A. Ma- 
ceina ${ }^{4}$. Tačiau neabejotinai vieni radikaliausių civilizacijos kritikų pasirodė Ludwigas Klagesas ir Spengleris. Civilizacijos ir kultūros disjunkcija buvo pamatas, kuriuo Spengleris grindè savo gyvenimo filosofiją ir kultūrinę ideologiją. Spengleris aiškiai nurodè, kad kultūros gyvenimas arba, kitaip sakant, kultūra, yra svarbus autentiško gyvenimo rodiklis. Kultūriniame gyvenime klesti individualumas, aktyvumas, meno, mokslo, filosofijos, religijos ir kūrybinių jẻgų klestëjimas. Problema iškyla tuomet, kai kultūrini ciklą keičia civilizacija, kurios technologijos ir poreikiai iš esmès sunaikina kultūrą ir jos galią bei autoritetą visuomenèje. Taigi remdamasis minèta priešprieša, Spengleris iškèlè ir plètojo minti, kad kultūros krizè sietina su civilizacijos iškilimu kaip žmogaus kūrybinių galių išsekimu, o kartu asmens dvasine ir vertybine krize.

Vakaru saulelydyje jis suformulavo savitą kultūros ir civilizacijos samprata, kuri turèjo didelę išliekančią ịtaką visai tolimesnei kultūros filosofijai. Žvelgdami lyginamuoju aspektu, matome radikalu skirtingumą tarp kultūros ir civilizacijos. Kultūra ir civilizacija skiriasi kaip diena ir naktis, kaip gyvenimas nuo mirties, kaip tai, kas gyva, juda, nuo to, kas sustingo ir nebeteko gyvybingumo ${ }^{5}$. Civilizaciją Spengleris ịvardija mirties era, o kultūrą - priešingai, aukščiausia vertybe, tautos gyvybès, jos moralinio dvasingumo ir išsivystymo išraiška. B. Bowden pažymi, kad visišką antagonizmą tarp kultūros ir civilizacijos yra išsakęs ir Nietzsche. Nietzsche teigè, kad didžiosios kultūros visada ugdè dvasios laisvę ir buvo moraliai kalbančios, o civilizacijos epochos auklèjo žmones kaip gyvu- lius, tai netolerancijos metai, sunkiausi žmogaus dvasiai ir prigimčiai ${ }^{6}$.

Spengleris pažymi, kad kultūros iškilimas pirmiausia siejamas su kūryba, kurios procese gimsta nauja kultūrinè forma. Todèl pirmas svarbus žingsnis, tyrinejjant kultūra, yra suprasti, kokiais regimais pavidalais ji pasireiškia istorijoje. Kiekviena kultūra savitus regimus vaizdinius igauna per kalba, religija, mena, etika, ìvairius literatūrinius kūrinius, politinius santykius ir pasaulèžiūras. Šiuose modeliuose ir kultūrinèse formose slypi unikalūs reikšminiai simboliai, kurie būdingi tik tai vienai konkrečiai žmogiškai kultūrai ir niekada istorijoje nepasikartoja. P. Sorokino teigimu, „,viso savo darbo metu Spengleris stengèsi parodyti, kaip kiekviena kultūra kuria savo asmeninį tipą ir suteikia unikalią prasmę bei stiliu menui, filosofijai, religijai, mokslui ir praktiškai visiems kultūriniams ir socialiniams reiškiniams ${ }^{17}$.

Tyrinėdami Spenglerio kultūrologinès nuostatas, galime matyti, kad jos yra nukreiptos prieš vakarietiškaji europocentrizmą ir tiesinès civilizacijos istorijos viziją. Pasaulyje, giliu šio filosofo įsitikinimu, skleidžiasi skirtingų kultūros formų ivvairovè. „Aš regiu spektaklį daugybès galingų kultūrų", - rašo Spengleris ${ }^{8}$. Kiekviena kultūra yra ypatinga kaip atskiras, uždaras, savarankiškas pasaulis. Ji kaip gyvas organizmas išgyvena atitinkamus raidos etapus - gimsta, bręsta ir miršta. Todèl, žvelgiant iš Spenglerio pozicijų, istorijoje nèra nei progreso, nei regreso, egzistuoja tik cikliškumas. Ši Spenglerio pozicija atmeta linijinę istoriją ir atspindi graikišką mitologini laiko suvokimą, kurị jis perima iš Nietzsche's. Klauso Fischerio pastebejjimu, Spenglerio mąstymo 
pirminės prielaidos savo kilme buvo graikiškos - jis susižavi graikų filosofais, būtent Herakleito nuolatinès kaitos idejja9 .

Taigi Spengleris kultūru prigimtyje ¡žvelgia nuolatinę ciklinę kaitą, kurią metaforiškai lygina su metų laikais. Kiekviename kultūriniame metu cikle slypi tam tikras lygis, kuri pasiekus iš esmès neišvengiamai pereinama i kitą etapą. Glaustai apžvelgiant kultūrinių ciklų analizę, galima pažymèti, kad trys laikų tipai - pavasaris, vasara ir ruduo - atspindi kultūrini laiką - kultūros vystymąsi, augimą ir saulèlydį. Paskutinëje žiemos pakopoje ìvyksta kultūros regresas, ji praranda kūrybinę potenciją bei gyvastingumą ir tampa civilizacija dirbtiniu mechanizmu. Apibendrinant šiuos ciklus, galima pasiremti Stuarto Hugheso pastebèjimais, kad „kultūros fazè - tai visuomenès kūrybinio aktyvumo laikotarpis, o civilizacija - teorinès sistemos ir materialinio komforto stadija. Pirmoji apima visuomenès pavasarị, vasari ir rudeni, antroji - jos žiemą ${ }^{\prime 10}$.

Šios ižvalgos leidžia pagrisstai teigti, jog Spengleris matė neatsiejamą ryši tarp kultūros ir kūrybos. Autentiška kultūra egzistuoja ir gali išlikti tik kaip gyvas organizmas, gyvoji kūrybos jèga, pasireiškianti formu gausa per ịvairias visuomenes, menines ir kultūrines formas. Taigi kultūriniu ciklu tapsmas ir vystymasis pirmiausia pasireiškia kaip kūrybinè jèga. Ir jeigu civilizacija turi polinki i stagnaciją ir dvasini pasyvuma, tai kultūra visa savo esybe reiškiasi dvasine kūryba, kova ir atsinaujinimu. Ir ši kūryba savitomis formomis ir unikaliais simboliais pasireiškia ne tik mene, bet ir politikoje, teisèje, literatūroje, moksle, filosofijoje ir visose žmogiškojo gyveni- mo ir veikimo srityse. Taigi nuo žmogaus vidinių kūrybiniu galiu priklauso ne tik jo gyvenimo kokybè ir asmenybės saviraiška, bet ir visos kultūros vystymasis. Kultūra, jos vertybès ir formos yra kūrybinès žmogaus galios išraiška.

Kultūrinei kūrybai ir jos formoms reikštis svarbu individualumas, spontaniškumas, intuicija. Todèl į civilizaciją Spengleris žvelgia kritiškai, nes civilizacijos intelekto raiška ir technikos suklestejjimas vis labiau užgožia ši natūralumą, spontaniškumą, kuri pakeičia dirbtinumas ir mechaniniai procesai, kurie žmogu padaro nelaisvu technikos vergu. Spengleris, kaip ir jo šalininkai - Schopenhaueris, Nietzsche, Bergsonas bei kiti gyvenimo filosofai, kritiškai žvelgdamas i klasikinèje metafizinèje filosofijoje puoselètą proto ir sistemos kulta, atsiriboja nuo racionalistinès pozicijos, aukštindamas iracionalu kūrybinį žmogaus pradą. Intelektas žmogų suvaržo, jame nebelieka laisvos kūrybinès dvasios, proto galia ribota - jis geba tik analizuoti ir interpretuoti, atkartodamas jau anksčiau sukurtas formas. Todèl, kaip tvirtina Spengleris, technikos iškilimas ir proto suabsoliutinimas nurodo autentiškos, originalios kūrybos stygių. Vadinasi, besiplètojanti dabarties visuomeneje techninè pažanga neatspindi dvasinès ir kultūrinès žmogaus pažangos, priešingai - ji slopina kultūrinių vertybių vystymąsi.

Jamesas Kiddas kritiškai pažymi, kad Spengleris veikale apie žmogų ir techni$\mathrm{ką}^{11}$ siekia paneigti savo ankstyvojo kūrybinio laikotarpio pesimistines idejas, kurias skelbè „Vakarų saulèlydyje“, teigdamas, kad technologijos reprezentuoja aukščiausią žmogaus pažinimo išraišką ir kūrybines kompetencijas. Minimas 
autorius kelia tezę, jog vèlesnio laikotarpio kūryboje iškyla Spenglerio tvirtinimai, kad modernios technologijos gali būti traktuojamos kaip paskutinè, aukščiausia žmogiškos kultūros vystymosi stadija $^{12}$. Tačiau nesuklysime teigdami, kad visuminiame Spenglerio kultūrinès krizės kontekste civilizacija yra suvokiama kaip dirbtinė ir kraštutinè būsena, baigiamasis kultūros etapas. Kultūros ir civilizacijos priešprieša iškyla kaip gyvo organizmo ir mirusios struktūros, kūrybos ir mechaniškumo antitezè. Kalbant paties Spenglerio žodžiais, tik kultūros dirvoje gimsta kūrybiniai genijai, civilizacija lieka tuščiagarbè, joje gimsta intelektualiniai herojai, kurių didžiausias galia yra analizè ir interpretacija ${ }^{13}$. Spenglerio sekèjas Berdiajevas, analizuodamas techninès civilizacijos ir kultūros priešstata, taip pat nurodo, kad civilizacija sustabdo kūrybinę asmens saviraišką. Kultūra išreiškia laisvą ir kūrybinį žmogaus dvasios sieki prasiskverbti anapus „objektu“" pasaulio, augti, kisti, formuotis, o civilizacijos siekis yra saugiai ir patogiai isitvirtinti „objektų" pasaulyje, ji užkariauti ir jame viešpatauti.

Taigi šiame tyrinèjimo kontekste matome, kad Spengleriui kultūros krizę ir pabaigą žymi civilizacijos era, neturinti nieko bendra su autentiška dvasine kūryba ir kultūra. Tad galime teigti, kad Spenglerio disjunkcija kultūra ir civilizacija atskleidžia radikalią skirti tarp kultūros ir antikultūros. Antikultūra apima viska, kas priešiška kultūrai, ir glaudžiai siejasi ne tik su kūrybine krize, bet ir su žmogiškųjų vertybių krize. Keliant klausima, ar galima kaip nors kultūrai išvengti šios tragiškos baigties, Spengleris atsakytų, kad ne - „,civilizacija yra neišvengiama kultūros lemtis“14. Taigi kultūros krizė yra neišvengiamas Vakarų istorijos likimas. Tai reiškia, kad visos pastangos išvengti krizès ar sustabdyti kultūros irimą yra bevaisės. Kultūrai jau nuo jos regimo pasirodymo yra lemta išnykti. Tą atskleidžia Spenglerio ciklinè kultūros teorija, pagal kurią kultūra traktuojama kaip mirtingas esinys. Ši mirtis ir sunykimas slypi pačioje kultūros prigimtyje, nes kitu atžvilgu kultūra nebūtų gyva, o tik mechaniška sistema. Anot Spenglerio, kaip ir kitos gyvosios gamtos formos, „kultūra pereina individualius žmogaus gyvenimo tarpsnius. Kiekviena iš jų pergyvena vaikystę, jaunystę, brandą ir senatvę ${ }^{\prime 15}$ ir galiausiai miršta. Stagnacija, kaip tam tikra kultūrinès krizès išraiška, gali užtrukti dar ilgus šimtmečius, visgi tai neišvengiamas procesas. Kultūra miršta, kai jos dvasinè prigimtis realizuoja visas vidines galimybes ir potencijas. Dèl to, anot Spenglerio, kultūros dvasinèje prigimtyje slypi nuolatinè itampa, prieštaravimas ir kova prieš beformiškumą, o kartu siekis ịveikti jau sukurtas kultūrines formas ir šitaip toliau kurti, realizuotis.

Simmelis savo veikale apie kultūros filosofiją ${ }^{16}$, paveiktas Spenglerio idejjų, skelbè, kad kultūros tragizmą nulemia tai, jog gyvenimas nuolat susiduria su savo paties sukurtomis formomis, o tai veda prie kultūrinès krizès situacijos. Juk forma yra tai, kas suteikia apibrèžti, galutini tikslą, vadinasi, nurodo kultūros užbaigimą. Taigi, viena vertus, galime teigti, kad sukurtos kultūros formos stabdo tolimesnę kūrybinę kultūros sklaida, kita vertus, kartu tai tampa nauju „iššūkiu“ iveikti kelyje pasitaikančią ribą kuriant naujas kultūros formas. 
Kaip jau buvo minèta, kalbėdamas apie kultūrų ciklus, Spengleris nurodo, kad kultūra, išgyvendama savo saulèlydi, tampa nebevaisinga, ji nebegali formuoti naujų formų ir pradeda nykti. Taigi civilizacija reiškia kultūros žlugimą ir mirti ta prasme, kad ji praranda gebejjimą kurti naujas, autentiškas kultūrines formas. Civilizacijoje kūryba pasireiškia tik kaip interpretacija, kopijavimas jau esamų kultūrinių ar meninių formų. Naudojant Spenglerio terminus, tokių formų sukūrimą ar sudarymą galima ivvardinti kaip pseudomorfozę. Pats dèmuo pseudo nurodo tai, kas netikra, tariama, apgaulinga. Todèl, kaip tvirtina Spengleris, būtina skirti autentiška, tikrą̧ą kūryba, tai yra kultūrinę kūryba, nuo civilizacijoje ìsitvirtinusios kūrybos. Kultūrinè kūryba visada yra nepakartojama, vienintelè ir originali, ji siekia kokybės ir vertès, o civilizacija ir masinė kūryba - kiekybès ir pelno. Taigi, remiantis šiomis ižvalgomis galima teigti, kad civilizacijoje formuojasi pseudokūryba, kuri, nesvarbu, ar meno, ar muzikos srityje, remiasi tik skonio ir sėkmės kultu, paviršutiniškumu, mėgdžiojimu, kopijavimu, siekiant suteikti pramogą masėms, patenkinti ju vartotojiškus poreikius ir šitaip igyti kuo daugiau garbès ir pelno. Tai rodo, kad laisvą ir autentišką kūrybą pakeičia betikslis kopijavimas ir manipuliavimas, izsigali mados kultas, paviršutiniški grožio standartai, kurie turi destruktyvų poveiki kūrybai ir kultūrai. Kultūros produktų kūrimas tampa verslu. Iš to kyla kultūros ir kūrybos devalvavimas ir nuosmukis. Menas, kuris yra vienas svarbiausių kultūros raiškos formų, civilizacijos epochoje nuvertëja, prarasdamas savo autoriteta, vertę ir simbolinị turinį.
Romantikai ir neklasikinès filosofijos tradicijos atstovai skelbè, kad būtent per muziką ir meno kūrinius geriausiai atsiskleidžia žmogiškosios egzistencijos prasmè ir būties slèpiniai. Akivaizdu, kad meno ir kultūrinès kūrybos krizè pasireiškia tuo, kad menas praranda šią savo prigimtinę paskirti. Kultūros produktai tampa tik perkama - parduodama ir greitai suvartojama preke. Toks kultūros masiškejjimas grindžiamas komercinèmis nuostatomis, todèl nepaisoma tradiciniu vertybių. Tai nulemia visuomenès demoralizaciją ir kūrybiškumo menkejjimą. "Itakingi postmodernizmo ideologai (Deleuze, Joseph Beuys, Günter Kunert, Jean Baudrillard), plètodami Schopenhauerio, Nietzsche's, Spenglerio, Theodoro Adorno, Heideggerio motyvus, prabyla apie postnihilistinę Vakarų civilizacija, kurią laiko nenatūraliu, negyvu organizmu, kuriame išnyksta gyvybinè energija, kūrybinis dvasios polèkis, sugebëjimas kurti reikšmingas vertybes. ${ }^{\text {17 }}$

Taigi Spengleriui kultūros krizè pasireiškia kaip žmogaus kūrybinių galių išsekimas ir autentiškos dvasinès kūrybos krizè. Berdiajevas knygoje Kūrybos prasme $^{18}$ asmens kūrybingumą laiko pagrindiniu žmogaus dvasios, jo asmenybės bruožu. Kūrybingumo nebuvimas rodo žmogaus nesugebejimą iprasminti savo egzistencijos, kurti savo gyvenimo, pasaulèžiūros ir kultūrinių vertybių. Berdiajevas, kaip ir Spengleris, priskiriamas tai filosofinei kultūrinei tradicijai, kuri skelbia, kad Vakarų Europa iššvaistè savo kūrybines galias ir jos kultūra yra krizinès būklès.

Apibendrinant šio skyriaus įžvalgas galima teigti, kad mūsų aptarta principi- 
nè kultūros ir civilizacijos skirtis nurodo kultūrą kaip aukščiausią visuomenès dvasinio ir moralinio išsivystymo stadija, o civilizaciją - kaip visuomenès tobulejjimo sąstingị. Kultūros vystymasis yra glaudžiai susijęs su prigimtine, sponta- niška, intuityvia žmogaus kūrybine galia. Civilizacijos eroje iškilę technologiniai laimèjimai ir masinès kultūros apraiškos nulèmė žmogaus kūrybiniu galių ribotumą ir išsekima, o kartu ir visu žmogiškujjų tradicinių vertybių nykimą.

\section{MIESTAS IR KAIMAS}

Spengleris kultūros ir civilizacijos nesuderinamumą ir prieštaringumą siekè pagristi miesto ir kaimo antiteze. Miestas yra civilizacijos produktas, todèl miestas ir jo „kultūra“ iš esmès yra kažkas visiškai priešinga kaimo kultūrai, kuri saugo tradicijas ir kultūros gyvajją dvasią. Čia tik glaustai verta paminèti, kad Spengleris atskyre ir teigiamai vertino kultūros epochoje susiformavusius miestus, kurie civilizaciniuose procesuose transformuojasi i galingus didmiesčius. Būtent technikos progresas sukuria gigantiškus pasaulinius miestus, kurie tampa kultūros žlugimo simboliu. „Miestas - megapolis, - rašo Spengleris, - tampa tuo tašku, kuriame susitelkia visų tolimų šaliu gyvenimas, o tuo metu likusioji dalis džiūsta. ${ }^{\prime 19}$ Spengleris ši procesą i̇vardija ne tik kaip kultūriniu vertybiu ir tradicijos nyksmą bet ir kaip žmogaus nuasmeninima, jo dvasinę degradaciją. Itakingas civilizacijos teoretikas Mumfordas Spengleri laiko svarbiu kultūros teoretiku, kuris atskleidè pražūtingą didmiesčio įtaką kultūrai ir žmogaus asmenybei, nurodydamas, kad visuomenès galių sutelkimas i vieną tašką turi destruktyvų poveiki kultūros gyvybingumui ir yra regimas kultūros krizès ženklas.

Analizuodamas motyvus ir priežastis, kodèl tokie didieji miestai yra kultūros regreso ir sustabarejjimo pradžia,
Spengleris nurodo daug vidiniu ir išoriniu pokyčiu, kuriuos sukuria ir įtvirtina miesto aplinka bei jo poreikiai. „Civilizacija ir miestai suformuoja inteligentiją - ambicingą, tuščiagarbę, skeptišką ir rafinuota, nekūrybingą ir be šaknų. " Žmogus tampa visiškai neprisirišęs prie savo vietos, aplinkos, tèvynès, jis tampa klajokliu ir emigrantu. Todèl iš esmès pakinta jo santykis su gimtają žeme ir tautiniu identitetu. Jam „ten, kur gerai,

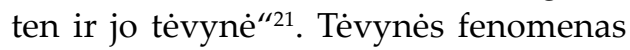
yra kultūrinis kaimo tradiciju paveldas, kuriame skleidžiasi prasmingas ir autentiškas žmogaus gyvenimas. Todèl žmogus, pasitraukęs iš kaimo i̇ didmiesčius, atitrūksta nuo savo gimtu ištakų ir gyvenimo pagrindų. Šitaip jis netenka gyvybinių energijų, būtinų kultūrinei kūrybai ir dvasiniam tobulejimui. Vadinasi, kultūros krizè kaip žmogaus kūrybinio potencialo išsekimas ivvyksta dèl to, kad prarandamas prigimtinis ryšys, kuris sieja individą su gimtąja žeme, tradicija, religija ir bendruomene. Anot Spenglerio, žmogus, emigruodamas svetur, tampa nevaisingas, jis persikelia $\mathfrak{i}$ kitas jam negiminingas kultūras, atitrūksta nuo savo tradicijos ir šeimos vertybių. Tai reiškia, kad kartu prarandama vidine savastis, tautinis tapatumas, istorinis jausmas, tévynė, o tai yra pamatas, iš kurio kyla autentiška kūryba, meno kū- 
rinys, tikrosios vertybès. "Autentiški kūriniai iškyla i paviršių iš žemès gelmių, nes joks tikras poetas, filosofas ar menininkas nekirsiąs savo šaknų ir nenutolsiąs nuo gimtojo kraštovaizdžio. Ryšio su tèviške praradimas nužudo kiekvieną tikrą talentą. "22 Todèl megapolis, internacionalumas, kosmopolitiškumas, globalizacija - šie civilizacijos dariniai naikina, suardo aplinka, kurioje tarpsta kūrybingas kultūros žmogus ir kultūrinès formos.

Taigi šiame kontekste matome, kad Spengleris, iškeldamas miesto ir kaimo priešprieša, siekè parodyti, kaip kultūra ir jos klestëjimas yra glaudžiai susiję su žmogaus gyvenimu, jo aplinka ir siela. Juk kultūra bendriausia prasme gali būti apibrèžta kaip žmogaus gyvenimo ir veiklos būdas. Miesto žmogaus sugebèjimai suprasti kultūra, jos tradicijų reikšmę smarkiai sumenkèja, maža to, jis kategoriškai atsiriboja nuo savo dvasiniu šaknų. Civilizacija ir racionalus mąstymas yra dirbtinis, nuo gamtos ir žmogaus atitrūkęs darinys. Provincijos žmogus, priešingai nei miestietis, yra gamtos žmogus, gyvenantis vienybejje su būtimi, su gamta ir žeme. Jis save supranta ir atranda kaip neatsiejamą nuo savo gimtujų namų, kaimo, vietovès tradicijos ir religinių formų. Tyrinejjant kultūros fenomena, yra pastebimas "glaudus kultūros ryšys su vietove, žeme, ji susijusi su žmogaus gyvenama aplinka ir kasdienybe, nes kultūra auga kaip augalas savo žemejje ${ }^{\prime 23}$. Todèl kultūra klesti toje aplinkoje, kur yra giliai issišaknijusi tradicija, tikejjimas bei tautinè savastis. Taigi apibendrinant galime teigti, kad kultūra savo pagrindą turi kaimo tradicijose ir aplinkoje, o civilizacija sukuria aplinka, kurioje dominuoja ne žmogaus natūrali prigimtis ir tradicija, o technika ir intelektas. Šia prasme žmogaus kūrybingumas susijęs su tam tikra socialine ir kultūrine aplinka, kuri ši kūrybingumą gali skatinti ir slopinti.

Vadinasi, žvelgiant iš Spenglerio pozicijų, civilizacijos sukelti aplinkos pokyčiai turi neigiamą poveiki žmogaus asmenybei, jo dvasinei kūrybai ir vertybinėms nuostatoms. Arba, kitaip tariant, kultūros nuosmukis ir krizė glaudžiai siejama su žmogaus dvasine krize. Civilizacijos žmogus, kaip nurodo Spengleris, - „tai naujas didmiesčio dirbtinis žmogus, klajoklis, parazitas, tradiciju nesaistomas, beformè masè, gryno fakto žmogus, nereligingas, nevaisingas, inteligentiškas, bergždžias, neorganiškas “24. Taigi šiame kontekste regime, kad kultūrinės krizès pasekmès gali būti suvokiamos ar perteikiamos per šią iš esmès morališkai deformuotą žmogaus asmenybę. Galiausiai Spengleris, parodydamas destruktyvias pasekmes, civilizacijos žmogu pavadina jau nebe žmogumi: tai "miestus statantis gyvūnas". Tad Spenglerio kultūros filosofijos kontekste kultūrinę krizę galime ìvardyti ir kaip miesto pergale prieš kaima, visa tai charakterizuoja didžiąją Vakarų kultūros pabaigą.

Schweitzeris, kuris buvo stipriai paveiktas Spenglerio kultūrologinių idejuç, analizuodamas Vakarų kultūros žlugimo priežastis, taip pat konstatuoja dvasini kultūros nuosmukị, kurị sukelia miestai: „Atèjo laikai, - rašo Schweitzeris, - kai reikia gelbèti kultūrą nuo dvasinès stagnacijos, dèl kurios kalti didieji miestai ir jų gyventojai“; ir toliau: „...laisvès praradimo ir mąstymo sumenkèjimo atžvilgiu blogiausioje padètyje atsidūrè didžiųju miestų žmonès “25. Miestai kuria visuomenę, kuri yra pilka ir bedvasè, nelaisva, 
valdoma nuomonès, stereotipu - tai masès. Toks masių kultūros iškilimas ir įsitvirtinimas yra svarbus kultūros krizès požymis. „Nietzsche gali būti vertinamas kaip vienas iš pirmujuc teoretikų ir kriti$\mathrm{ku}$, gilinęsis i moderniosios kultūros negatyviuosius gyvenimo aspektus. Nietzsche masinę kultūrą suprato kaip dekadanso ir nihilizmo jèga, paveikusią autentiškają kultūrą ir kuriančią vidutinybių kultūrą. Jis skelbė, kad masès veda link minios konformizmo, produkuoja masinį manipuliavimą ir homogenizavima, žalojančius vitalinę gyvenimo energija, kūrybiškumą ir aukščiausiąji individualumą. ${ }^{\text {26 }}$ Nietzsche's išplètota nuosekli masinès kultūros kritika turëjo dideli poveikị Spenglerio kultūrinèms idèjoms. Masių kultūra, pasak Spenglerio, visiškai priešinga aukštajai kultūrai, masès su neapykanta persekioja ir naikina bet kokią kultūrinę forma, vertybes, individualuma, žinias ${ }^{27}$. Spenglerio sekëjas Ortega y Gassetas, pratęsdamas Spenglerio izžvalgas, savo knygoje Masiu sukilimas stulbinamai perteikè masių issigalejjimą ir jų pražūtingą pavojų Vakarų visuomenei ir kultūrai. Masės žmogus suvokiamas kaip inertiška asmenybé, kuri yra dvasiškai neveikli, nerangi, ribota, pasyvi, vartotojiška, nekūrybinga, uždara. Todèl masių iškilimas ženklina didžiąą kultūros ir vertybių krizę, hierarchinių kultūros principu ir normų eroziją ${ }^{28}$.

Taigi Spenglerio ir jo bendraminčių kritinès įžvalgos atskleidžia, kad didžiųjų miestų formuojama ir diktuojama masinė kultūra persmelkta vartotojiškos ir pragmatiškos dvasios ir iš esmès sunaikina autentiškos kultūros ir vertybių pamatus, ji paneigia žmogų kaip svarbiausią kultūros kūrèją, užkerta kelią formuoti autentiškos kultūros formas ir destruktyviai veikia žmogaus asmenybę ir jo gyvenimą.

Tad glaustai, lyginamuoju aspektu žvelgiant, megapolio ir kaimo aplinka turi skirtingą poveiki kultūrai, asmens kūrybiniam gyvenimui ir vertybèms. Didmiesčio aplinkoje klesti masinè kultūra, sẻkmès ir mados kultas, stereotipai, paviršutiniški grožio standartai, pragmatizmas. Tai svarbūs veiksniai, stabdantys kultūros pažangą. Provincijos aplinkoje, priešingai, klesti autentiška kultūra, individualumas, intuicija, natūralumas, laisvè, tradicija, vertybès. „Civilizacijos ir kultūros nesuderinamumą galima apibrèžti dar viena svarbia opozicija religinis tikejimas ir ateizmas. Būtent religinè problema Spenglerio filosofijoje glaudžiai susijusi su kaimo ir megapolio skirtumu. Mat tikrasis religinis tikèjimas kyla iš žmogaus širdies, bet ne iš proto, todèl megapolio žmonèms tampa neįmanoma tikèti, nes ju gyvenimą valdo mechaniškas intelektas. ${ }^{\text {29 }} \mathrm{O}$ tai iš esmès keičia žmogaus dvasini pasauli, jo būtí, egzistencijos pajautima, visumini pasaulio matymą.

Taigi trumpai apibendrinant galima teigti, kad civilizacija nuasmenina, dehumanizuoja žmogu, suformuodama masès žmogų, kuris tampa nelaisvu, nekūrybingu, beveidžiu žmogumi ir kuri visiškai ittraukia ir niveliuoja miesto aplinka ir industrija. Vadinasi, iškilus civilizacijai ir ísitvirtinus didmiesčiams, tiek kultūra, tiek asmenybè praranda prasmingos, kūrybingos egzistencijos pamatus. Visa tai atspindi Spenglerio kultūrinès krizès sampratą bei jos pasekmes.

Spengleris neslèpè savo pesimizmo ir nusivylimo esama Vakarų kultūros padètimi, kuri, jo giliu îsitikinimu, byloja apie kultūros gyvybinès energijos iš- 
sekimą ir žmogaus asmens, jo gyvenimo krizę, šitaip suartėdamas su gyvenimo filosofijos tradicija. Jam, kaip ir Schopenhaueriui, buvo visiškai nesuprantamas apgaulingas Vakaru žmogaus optimizmas, kuris buvo paremtas tolimesnès kultūrinès pažangos koncepcija. Jo veikale Vakaru saulèlydis kultūrinès krizès samprata atskleidžia giliai pesimistinę, tragišką Vakaru kultūros žlugimo teoriją. Tokiomis tragiškomis nuostatomis Spengleris buvo ypač artimas Nietzsche's kultūrinei ir gyvenimo pozicijai. Abu vokiečiu mąstytojai įvardijo Vakarų kultūros būklę kaip dekadansą ir žmogaus kūrybinių potencijų silpnèjimą.

\section{IŠVADOS}

Spenglerio kultūros filosofijoje iškylanti radikali kultūros ir civilizacijos skirtis žymi sudètingus civilizacijos istorijos virsmus, kurie atskleidžia gelmines gyvybingumą prarandančios Vakaru kultūros krizès priežastis ir padarinius. Keliamos kultūrinè krizès problemos Spenglerio filosofijoje glaudžiai siejasi ne tik su cikliniais kultūros raidos procesais, tačiau ir su žmogaus asmenybe, jo vidiniais kūrybiniais polèkiais, gyvenimo dvasine ir moraline kokybe, gyvenamaja aplinka, vertybinemis orientacijomis.

Atlikta Spenglerio koncepcijos ir jo pirmtakų bei amžininkų teoriju lyginamoji analizė išryškina svarbius skirtumus tarp kultūros ir civilizacijos. Pirmiausia, kultūra iš tikrujų apima tai, kas unikalu, natūralu, autentiška, ji nuolat judri ir besiplètojanti. Kultūros esmè kūryba ir tapsmas, dvasinio gyvenimo klestëjimas, humaniškumas, individualumas ir asmens laisvè. Civilizacija, priešingai, iškeldama technikos ir intelekto suabsoliutinima, vis labiau riboja žmogaus kūrybinę laisvę, žymi kultūrinių formu stagnaciją ir žlugimą. Jos esmè tai technologijos, racionalizmas, pragmatizmas, kai prigimtini natūralumą ir organiškumą keičia dirbtiniai ir mechaniniai dalykai.
Galiausiai, galime teigti, kad kultūrinès krizės priežastys susijusios su įvairiais visuomeniniais, vertybiniais aplinkos pokyčiais, kuriuos sukelia civilizacijos iškilimas. Kaip to rezultatas ir pasekme įsigali materializmas, kultūros komercializacija, vartotojiškumas, formuojasi masinè kultūra ir pseudokūryba, kuri slopina kultūros autoritetą ir autentišką kūrybą. Kultūrinè kūryba yra unikali, vertinga, pirmapradiška, kyla iš žmogaus sielos gelmių. Civilizacijoje, kurią valdo intelektas, vietoj autentiškos, originalios kultūrinès kūrybos įsitvirtina pseudokūryba, orientuota i kopijavima, mėgdžiojima, siekiant kiekybès ir naudos. Masinès kūrybos produktai, propaguodami mados kultą ir paviršutiniškus vartotojų standartus, destruktyviai veikia autentišką kultūrą jos formas, kultūros vertę ir galią visuomenëje. Tampa aišku, kodèl Spengleris kultūra, žyminčią autentiškumą ir kūrybini aktyvuma, iškelia kaip aukščiausią visuomenès dvasinio ir moralinio išsivystymo stadija, o civilizacija kurią ženklina technika ir intelekto viešpatavimas, sieja su antikultūra, t. y. kultūros baigtimi ir visuomenès tobulëjimo sąstingiu.

Todèl neatsitiktinai kultūros ir civilizacijos santykiu prieštaringumą Spengleris pagrindžia miesto - megapolio ir 
kaimo antiteze. Megapolis yra civilizacijos simbolis, jis pirmiausia susijęs su materialistine žmogaus gyvenimo puse, komfortu, masiniais standartais, kosmopolitizmu, o kaimas, priešingai - su kultūra, dvasine žmogaus gyvenimo puse, tradicijomis, religija, gamta, vertybèmis, individualumu. Kultūra gali gyvuoti tik

\section{Literatūra ir nuorodos}

1 Antanas Maceina, Kultūros filosofijos įvadas. Raštai. T. 1. Vilnius: Mintis, 1991, p. 88.

2 Juozas Girnius, Tauta ir tautinè ištikimybè. Raštai. T. 3. Vilnius: Mintis, 1995, p. 45.

${ }^{3}$ Antanas Andrijauskas, Lyginamoji civilizacijos ideju istorija. Vilnius: Vilniaus Dailès Akademijos leidykla, 2001, p. 474.

${ }^{4}$ Leonidas Donskis, Moderniosios kultūros filosofijos metmenys. Vilnius: mokslo ir enciklopediju leidykla, 1993, p. 23.

${ }^{5}$ Pgl. Oswaldas Spengleris, Vakaru saulèlydis. Kultūros fenomenas. Kultūra ir civilizacija. Iš vokiečiu k. vertė Eligijus Raila. Vilnius: Gervelè, 1999.

${ }^{6}$ Brett Bowden, The ideal of civilisation: Its origins and socio-political Character. Critical Review of International Social and Political Philosophy 7(1), 2004, p. 40.

7 Pitirim Sorokin, Social Philosophies of an Age of Crisis. Boston: The Beacon Press, 1950, p. 82.

8 Oswaldas Spengleris. Vakaru saulèlydis, 1999, p. 199.

9 Klaus Fischer, History and Prophecy: Oswald Spengler and the Decline of the West. New York: Peter Lang Publishing, 1989, p. 81.

${ }^{10}$ Henry Stuart Hughe, Oswald Spengler: A Critical Estimate. New York: Charles Scribner's Sons, 1962, p. 72.

11 Plačiau žr. Oswald Spengler, Man and Technics: A Contribution to a Philosophy of Life (1931). Trans. Charles Francis Atkinson. New York: Alfred A. Knopf, 1976.

12 Ian James Kidd, Oswald Spengler, Technology, and Human Nature. Toward New Paradigms. The European Legacy 17(1), 2012, p. 19-31.

13 Pgl. Oswaldas Spengleris. Vakaru saulèlydis, 1999. natūralioje aplinkoje, todèl Spengleris civilizaciją vertina negatyviai, nes didmiesčių aplinka nulemia autentiškos kultūros regresą ir pabaigą. Ir pagaliau, kultūrinė krizė įvyksta dèl neišvengiamų istorijos ciklų kismo, tai reiškia, kad visos pastangos išvengti kultūros krizès ar sustabdyti kultūros irimą yra bevaisès.

14 Освальд Шпенглер, Закат Европьы. Москва: Мысль, 1993, с. 135.

15 Oswaldas Spengleris, Vakaru saulèlydis. 1999, p. 210.

16 Plačiau žr. Georg Simmel, Sociologija ir kultūros filosofija. Iš vokiečių $\mathrm{k}$. vertė A. Lozuraitis. Vilnius: Margi raštai, 2007.

17 Antanas Andrijauskas, Lyginamoji civilizacijos ideju istorija. 2001, p. 465.

18 Plačiau žr. Николай Бердяевъ. Смысл творчества. Философия творчества, культурь и искусства. Т. 1. Москва: Искусства, 1994.

19 Oswaldas Spengleris, Vakaru saulèlydis, 1999, p. 212.

20 Leonidas Donskis, Oswaldas Spengleris: kultūros morfologija ir tragiška vaizduotè, 2007, p. 271.

21 Освальд Шпенглер, Закат Европьл. 1993, с. 92.

22 Leonidas Donskis, Oswaldas Spengleris; kultūros morfologija ir tragiška vaizduotè, 2007, p. 272.

23 Tony Bennett, Cultural Studies and the Culture Concept. Cultural Studies 29(4), 2005, p. 553-555.

24 Oswaldas Spengleris, Vakaru saulèlydis, 1999, p. 212.

25 Albertas Šveiceris, Kultūra ir etika. Iš vokiečių k. vertè Alfonsas Tekorius. Vilnius: Mintis, 1989, p. 45 .

26 Vesna Stanković Pejnović, The project Skopje 2014 from the perspective of mass culture criticism of F. Nietzsche. Creativity Studies 8(1), 2015, p. 58-71.

27 Освальд Шпенглер, Закат Европь, 1993, с. 377.

28 Pgl. Chose Ortega y Gasset, Masiu sukilimas. Iš ispanų k. vertė E. Treinienè. Vilnius: Mintis, 1993.

29 Gábor Kovács, The myth of the wicked city in the cultural criticism of O. Spengler. Limes: Borderland Studies 4(1), 2011, p. 69. 